\title{
ФОРМУВАННЯ ЛІДЕРСЬКОЇ КОМПЕТЕНТНОСТІ ПІД ЧАС НАВЧАННЯ В ЗАКЛАДАХ ВИЩОЇ ОСВІТИ
}

\author{
${ }^{1}$ Кротюк В. А., к. фр. н., дочент \\ ${ }^{2}$ Кислий В. Д., к. псих. н, дочент \\ ${ }^{3}$ Зоркін Р. Ю. \\ ${ }^{4}$ Яндола К. О. \\ Україна, м. Харків, \\ Харківський національний університет Повітряних Сил імені Івана Кожедуба \\ ${ }^{1}$ начальник кафедри психології та педагогіки, полковник \\ ${ }^{2}$ професор кафедри психології та педагогіки \\ ${ }_{3}^{3}$ викладач кафедри психології та педагогіки \\ ${ }^{4}$ старший викладач кафедри психології та педагогіки
}

DOI: https://doi.org/ 10.31435/rsglobal_ws/30092018/6140

\section{ARTICLE INFO}

Received: 08 July 2018

Accepted: 15 September 2018

Published: 30 September 2018

\section{KEYWORDS}

leader,

competence,

leadership competence, pedagogical technologies, critical thinking.

\begin{abstract}
In the article the urgency of acquiring leadership competency by modern specialists of any branches is emphasized; the definitions of such concepts as "leader" and "competence" are analyzed, on the basis of which the generalization of the category "leadership competence" is made. The authors reveal the essence of leadership competence through its components, namely: knowledge, skills, responsibility. It the article the practical recommendations on the application of modern pedagogical technologies and teaching methods for higher education applicants in order to stimulate the formation of leadership competences during higher education institutions training are provided.
\end{abstract}

Citation: Кротюк В. А., Кислий В. Д., Зоркін Р. Ю., Яндола К. О. (2018) Formuvannia Liderskoi Kompetentnosti pid Chas Navchannia v Zakladakh Vyshchoi Osvity. World Science. 9(37). doi: 10.31435/rsglobal_ws/30092018/6140

Copyright: ( 2018 Кротюк В. А., Кислий В. Д., Зоркін Р. Ю., Яндола К. О. This is an open-access article distributed under the terms of the Creative Commons Attribution License (CC BY). The use, distribution or reproduction in other forums is permitted, provided the original author(s) or licensor are credited and that the original publication in this journal is cited, in accordance with accepted academic practice. No use, distribution or reproduction is permitted which does not comply with these terms.

Вступ. Завдання сучасних закладів вищої освіти створити платформу для формування та розвитку національно свідомої всебічно розвинутої особистості зі сформованою моральною, художньо-естетичною, правовою, трудовою, фізичною та екологічною культурою. Розвиток людського потенціалу стає важливим фактором розвитку суспільства загалом. Державі необхідні професійно підготовлені фахівці, які здатні з одного боку чітко та якісно виконувати функціональні обов'язки, а 3 іншого - інноваційно мислити, приймати нестандарті рішення, працювати в умовах невизначеності, глибоко осмислювати свої недоліки й професійні надбання, розуміти значення безперервного професійного саморозвитку. Крім того, сучасні фахівці будь-якої галузі повинні мати комунікативні навички, вміти долати комунікативні бар'єри, співпрацювати та налагоджувати ділові стосунки 3 колегами й партнерами, організовувати власну діяльність та діяльність інших для досягнення спільної мети тощо. Все перераховане вище $є$ складовими лідерської компетентності.

Проблема лідерства та формування лідерських компетентностей $\epsilon$ сьогодні дуже актуальною. Це підтверджується зростаючою кількістю наукових праць за даним питанням закордонних та вітчизняних науковців в області педагогіки, психології, філософії, політології, економіки, соціології тощо. 
Так, питання лідерства висвітлені в наукових працях таких науковців, як: Н. Агаєв, Г. Андрєєва, В. Бондаренко, А. Лутошкін, О. Мармаза, Б. Паригін, О. Пономарьов, О. Романовський, Н. Семченко, Л. Уманський, Ф. Хміль, З. Черваньова, С. Шацький, В. Ягодніков та ін.

До питань компетентності зверталися в своїх роботах Н. Бібік, С. Бондар, С. Вітвицька, Н. Волкова, М. Головань, І. Зимня, І. Зязюн, О. Пометун, Г. Селевко, Ю. Татур, А. Хуторський тощо.

Зокрема, питання лідерської компетентності в різних сферах підіймаються в роботах
Р. Блейка
Н. Болгаріна,
А. Болдвіна,
Д. Виханського,
В. Весніна,
А. Кальянова,

Н. Мараховської тощо.

Незважаючи на значну кількість наукових робіт, складність лідерства як соціального феномена й досі залишає невирішеними низку питань, починаючи 3 визначення категорії «лідерська компетентність», виокремлення іiі складових, з'ясування, які умови повинні бути створені в закладах вищої освіти, щоб максимально забезпечити її формування.

Метою даною статті $\epsilon$ розкриття сутності поняття «лідерська компетентність» та формулювання практичних рекомендації щодо удосконалення організації навчального процесу в закладах вищої освіти, спрямовуючи його на створення платформи для формування та розвитку майбутніх лідерів.

Для досягнення поставленої мети необхідно визначити поняття «компетентність», «лідер», «лідерська компетентність», розглянути педагогічні методи та технології, які дозволяють формувати лідерську компетентність здобувачів вищої освіти в процесі навчання.

Результати дослідження. Досліджуючи поняття «компетентність» зазначимо, що в словниках воно визначається як: набута у процесі навчання інтегрована здатність особистості, яка складається із знань, досвіду, цінностей і ставлення, що можуть цілісно реалізовуватися на практиці [3]; поінформованість, обізнаність, авторитетність [12, с. 282]; компетентність як властивість за значенням компетентний, тобто: 1) такий, що має достатні знання в якій-небудь галузі; який 3 чим-небудь добре обізнаний; тямущий; який грунтується на знанні; кваліфікований; 2) який має певні повноваження; повноправний, повновладний - вживається у тлумачному словнику української мови [13, с. 250].

В інших джерелах зустрічаємо такі трактування цього поняття: «ступінь кваліфікації працівника, яка дозволяє успішно вирішувати задачі, що стоять перед ним» [2]; «динамічне поєднання когнітивних та метакогнітивних умінь та навичок, знань i розуміння, міжособистісних, розумових та практичних умінь і навичок, а також етичних цінностей» [4]; «інтегральна якість особистості, що виявляється в загальній здатності та готовності до діяльності, яка базується на знаннях і досвіді, здобутих у процесі навчання і соціалізації й орієнтованих на самостійну й успішну участь у діяльності» [11, с. 139]; «інтегрована якість особистості, здатність продуктивно виконувати діяльність у певних соціально-значущих сферах, на основі здобутих знань, умінь, навичок, досвіду, ставлень та цінностей» [7] .

Щодо видів компетентності, то в літературі зазначені наступні: функціонально (професійна), інтелектуальна, часова, соціальна, ситуативна [2]; професійні, методичні, соціальні [1]; функціональні (професійна), інтелектуальні, ситуативні, соціальні [6]; концептуальні (наукові), інструментальні, інтегровані, контекстуальні; адаптивні, комунікативні [9].

При побудові освітнього процесу в межах компетентнісного підходу виокремлюють надпредметні (міжпредметні) компетентності - вони можуть бути представлені, як «ключові», «базові»; загальнопредметні компетентності (освітні галузі); спеціально-предметні (стосовно певного предмету) [1, 6, 9].

Отже, аналіз літературних джерел дає можливість стверджувати, що хоч лідерська компетентність і згадується в наукових роботах, але їі не виокремлюють серед перерахованих класифікаційних ознак.

Розуміння сутності лідерської компетентності неможливо без розуміння самого поняття «лідер». В сучасних наукових джерелах «лідер» тлумачать як: «той, хто веде; перший, що йде попереду. Член групи, всі учасники якої визнають його керівництво, покладаються на нього в прийнятті серйозних рішень і вирішенні важливих проблем. ... неформальне лідерство - це процес впливу на людей за допомогою своїх здібностей, вміння чи інших ресурсів» [3]; «член групи, якому вона надає право приймати найвідповідальніші рішення, що стосуються інтересів усієї групи». Г87; «перший, головний, за ким йдуть, на кого рівняються, хто визначає поведінку інших. Лідер у парі - той, хто веде іншого, чия поведінка визначає поведінку підлеглого. Лідер у команді - той, хто веде за собою команду, той, чий вплив на групу більше, ніж у інших» [5]; «особистість, що користується визнанням та авторитетом у групі і за якою група визнає право 
приймати рішення щодо дії у важливих ситуаціях, бути організатором діяльності групи і регулювати відносини в ній» [10].

Виокремлюють й лідерські якості: комунікабельність, переконливість, тактовність, дипломатичність, гнучкість, розвинуті мовленнєві та організаційні здібності, цілеспрямованість, рішучість, впевненість у собі, вимогливість, здатність нестандартно мислили, ризикувати, прагнення до самоосвіти та самовдосконалення тощо.

Отже, виходячи із сутності понять «компетентність» та «лідер», а також враховуючи чисельні лідерські якості, визначимо лідерську компетентність наступним чином.

Лідерська компетентність - інтегрована якість особистості, яка характеризує здатність проявляти певні риси лідера в залежності від ситуації, яка склалась, намагаючись максимально повно використати власний внутрішній потенціал та потенціал своїх послідовників для досягнення поставленої мети.

Серед структурних елементів лідерської компетентності можна визначити такі:

- знання: сучасних теорій лідерства; психологічних особливостей лідерства; стилів управління; технологій та методів ефективного командного управління; основ конфліктології тощо;

- уміння та навички: управляти власним емоційним станом та емоціями інших; налагоджувати ефективні комунікації із послідовниками та іншими лідерами й групами; навчати лідерству інших, ефективного делегування; уміння долати та нівелювати конфлікти; комбінувати стилі управління в залежності від ситуації; генерувати власні ідеї з подальшим їх просуванням, а також стимулювати до генерування ідей інших тощо.

- відповідальність: за результати прийняття або неприйняття певного рішення; за добір способів і засобів керівного впливу; за власні результати та результати команди; за достовірність і релевантність інформації, що передається від лідера групі; за якість комутаційних процесів тощо.

Більш детально знання, вміння та навички повинні конкретизуватися враховуючи специфіку галузі, в якій діє лідер.

Набуття зазначених знань, навичко та вмінь відбувається протягом тривалого часу, але провідну роль в їх формуванні відіграють саме заклади вищої освіти, створюючи платформу для формування лідерської компетентності.

Основну увагу при цьому слід приділити педагогічним методам та технологіям, які використовуються в освітньому процесі.

Серед сучасних педагогічних технологій особливого значення набувають технології критичного мислення та створення ситуацій успіху в освітньому процесі.

Під критичним мислення розуміють таке мислення, при якому осмислюючи досвід формується власна думка, незалежно від обставин та інших людей. Рішення приймається на основі ланцюга доказів. В загальному вигляді критичне мислення передбачає розгляд ідей 3 багатьох точок зору; це певна система суджень, які допомагають аналізувати та формулювати обгрунтовані висновки.

3 педагогічної точки зору критичне мислення розглядають як комплекс мисленнєвих операцій, що характеризується здатністю людини: аналізувати, порівнювати, синтезувати, оцінювати інформацію з будь-яких джерел; бачити проблеми, ставити запитання; висувати гіпотези та оцінювати альтернативи; робити свідомий вибір, приймати рішення та обгрунтовувати його.

Застосуванням методів критичного мислення передбачає дотримання певної структури. Для реалізації технології критичного мислення можуть бути застосовані різні педагогічні методи та прийоми.

Так, на стадії «виклик» пропонуємо такі методи: кластер, асоціативний кущ, дерево передбачень, таблиця «Знаю, хочу, вмію», мозковий штурм, робота в парах, кошик ідей, правильні не правильні судження, діаграма Венна, INSERT, Ромашка (куб) Блума.

Стадія «осмилення» може бути реалізована за допомогою таких методів: ажурна пилка, дискусія, «тонкі» і «товсті» запитання, Т-таблиця, навчаючи вчуся, асоціативний кущ, mindmap, діаграма Ісікава, метод 6 капелюхів, метод вигаданих персонажів, метод синектики, Ромашка (куб) Блума, RAFT-технології, метод номінальних груп, метод Дельфі.

Написання сенканів, створення кластерів, заповнення таблиці «Знаю, хочу, вмію», методи ПРEC, INSERT, Ромашка (куб) Блума дають можливість здійснити рефлексію.

3 метою активізації навчально-пізнавальної діяльності тих, хто навчається вважаємо за доцільне використання прийомів створення ситуації успіху на заняттях. Від викладача вимагається дотримання наступних правил: демонстрація впевненості в тому, що всі здобувачі 
вищої освіти здатні засвоїти матеріал, оволодіти вміннями та навичками; заохочення до пізнавальної активності; акцентування уваги на розумінні, а не механічному запам'ятовуванні начального матеріалу; використання проблемно-пошукового підходу; створення відносин співробітництва і взаємодопомоги між самими здобувачами освіти та викладачем тощо. Досягти цього можна за допомогою таких психолого-педагогічних прийомів: «емоційна підтримка», «надаємо шанс», «емоційний сплеск», «обмін ролями», «еврика», «інтелектуальна інверсія», «лінія горизонту» тощо.

Особливе місце у формуванні лідерських якостей відіграє організація освітнього процесу із застосуванням технологій акмеологічного підходу, тобто використання: різних групових методів активного навчання (мозковий штурм, синектика, ділові та рольові ігри, аналіз проблемних ситуацій, евристичні методи); рефлексивних практикумів; технологій заснованих на принципах саморегуляції; особистісно-орієнтованих методів (гештальт-тренінги, аутопсихологічні тренінги).

Крім того, доцільно проводити діагностику лідерських якостей тих, навчається. Вона може бути здійснена за допомогою низки методик: методика оцінки загальної здібності до управлінської діяльності Л. Кудряшової, методика діагностики лідерських здібностей (С. Жаріков, Є. Крушельницький), методика діагностики схильності до певного стилю керівництва (С. Ільїн), шкала темпераментів Л. Терстоуна (в адаптації В. Хойновського), шкала самоефективності Р. Шварцера та М. Єрусалема, особистісний опитувальник Т. Лірі, методика діагностики соціального інтелекту Дж. Гілфорда, методика визначення рівня емоційного інтелекту (Н. Холл), методика оцінки рівня домагань В. Горбачевського тощо.

Висновки. Отже, вважаємо, що систематичне та комплексне застосування зазначених педагогічних технологій та методів в освітньому процесу в закладах вищої освіти сприятимуть формуванню як загальних рис лідера (емоційний інтелект, психологічна надійність, адекватна самооцінка, самосвідомість, впевненість, саморегуляція тощо), так й специфічних (лідерська спрямованість, лідерський потенціал, харизма, прагнення до успіху, готовність до змін тощо).

\section{ЛIТЕРАТУРА}

1. Базаров Т. Ю. Компетенции будущего: квалификация, компетентность (критерии качества)? / Т. Ю. Базаров // Открытый университет - М.: НИИ Механики МГУ, 2003. - С. 510 -539.

2. Балабанова Л. В. Управління персоналом / Л. В. Балабанова, О. В. Сардак .- К.: Центр учбової літератури, 2011. - 468 с.

3. Вільна енциклопедія Вікіпедія [Електронний ресурс] : [Веб-сайт]. - Електронні дані.Режим доступу : https://uk.wikipedia.org/wiki/.

4. Вступне слово до проекту ТЬЮНІНГ - гармонізація освітній структур у Європі. Внесок університетів у Болонський процес. [Електронний ресурс] : [Веб-сайт]. - Електронні дані. - Режим доступу: http://www.unideusto.org/tuningeu/images/stories/documents/General_Brochure_Ukr ainian_version.pdf,

5. Енциклопедія практичної психології Психолос [Електронний ресурс] : [Веб-сайт]. -Електронні дані. - Режим доступу : psychologis.com.ua/prakticheskaya_psihologiya.htm.

6. Задьора Т. Г. Професійна компетентність педагога як одна з умов його успішної професійної діяльності / Т. Г. Задьора [Електронний ресурс] : [Веб-сайт]. - Електронні дані. - Режим доступу : https://infourok.ru/vsitup_do_pedagogchno_radi_profesyna_kompetentnst_ pedagoga_yak_odna_z_umov_yogo_uspshno-292728.htm.

7. Марущак О. М. Поняття компетентності у педагогічній діяльності / О. М. Марущак // Креативна педагогіка: [наук.-метод. журнал] / Академія міжнародного співробітництва з креативної педагогіки «Полісся». - Житомир, 2016. - Вип. 11. - С. 97 - 108.

8. Основи психології [Електронний ресурс] : [Веб-сайт]. - Електронні дані. - Режим доступу : https://pidruchniki.com/1685030337343/psihologiya/lider_liderstvo.

9. Пометун О. I. Теорія та практика послідовної реалізації компетентнісного підходу в досвіді зарубіжних країн / О. І. Пометун // Компетентнісний підхід у сучасній освіті: світовий досвід та українські перспективи. Бібліотека з освітньої політики - К.: «К.І.С.», 2004. - С. 15-25

10. Прищак М. Д., Мацко М. А. Психологія: навчальний посібник / М. Прищак, М. Мацко ГЕлектронний peсурс] : [Веб-сайт]. - Електронні дані. - Режим доступу : http://posibnyky.vntu.edu.ua/corner/133.html.

11. Селевко Г. Компетентности и их классификация / Г. Селевко // Народное образование. - 2004. - № 4. - С. 138 - 143.

12. Словник іншомовних слів / Уклад.: С. М. Морозов, Л. М. Шкарапута. - К.: Наукова думка, 2000. 680 с. Словник української мови: в 11 т. / [ред. колег. І.К. Білодід (голова) та ін.]. - К.: Наукова думка, 1970 - 1980. - Т. 4: I - М / [ред. А. А. Бурячок, Г. М. Гнатюк, П.П. Доценко]. - К.: Наукова думка, 1973. -840 с. 